\title{
Narasi Tragis Dalam Manga : Sebuah Kajian Estetika Aristotelian Terhadap Komik 5 Centimeters per Second
}

\author{
Aditya Nirwana $^{1}$, Evelyne Afriliana Gultom ${ }^{2}$ \\ ${ }^{1,2}$ Desain Komunikasi Visual/Universitas Ma Chung \\ 1aditya.nirwana@machung.ac.id,2331510009@ student.machung.ac.id
}

\begin{abstract}
ABSTRAK
Komik telah menemukan posisi dan urgensinya dalam keilmuan seni maupun sastra sebagai seni sekuensial, keberadaanya diapresiasi baik dalam seni rupa maupun sastra. Kajian ini menyoroti aspek kesusastraan atau aspek ideoplastis dari komik 5 Centimeters per Second, dari segi alur, karakter dan perwatakan. Tujuan dari kajian ini menjelaskan bagaimana tragedi diungkapkan. Teori yang dipergunakan adalah konsep Tragedy dari Aristoteles, yang berinduk pada karyanya Poetics sebagai karya filsafat klasik Yunani. Dengan penjelasan mengenai alur dan perwatakan dari komik yang memiliki keunggulan dalam dua hal(capaian teknis visual dan kesusastraan), hasil dari kajian diharapkan dapat menjadi pertimbangan dalam membuat komik. Hasil dari kajian ini manga hadir dengan mengimitasi obyek-obyek, peristiwa, tindakan, dan watak dalam kategori moral yang lebih baik daripada manusia pada umumnya. Dalam kisah manga ini, nyaris semua tokoh('aktor' dalam terminologi Aristoteles) sadar bagaimana harus bertindak, mereka tahu tetapi tidak melakukannya, akhirnya tenggelam dalam penderitaan. Menurut Aristoteles, kisah tragis seperti ini adalah terburuk.
\end{abstract}

Kata Kunci : komik, manga, poetics, aristoteles, tragedi

\begin{abstract}
Comics, or in Indonesian, are often referred as cergam (cerita bergambar), so far they have found their urgency in the science of art and literature as a sequential art, which existence can be appreciated both in art and literature. This study highlights the literary aspects or ideoplastic aspects of 5 Centimeters per Second, especially in the plot, character, and characterization. The purpose of this study is to reveal or explain how the tragedy was revealed in 5 Centimeters per Second. In achieving these objectives, the theorization in this study was done deductively to answer the research questions. The theory used to explain the problem is the concept of Aristoteles' Tragedy, which relates to his Poetics work as a work of classical Greek philosophy. With an explanation of the plot and the order of comics that have exellences in two aspects (visual and literary technical achievements). The results of this study are expected to be a consideration in making comics. The results of this study conclude that the manga presented by imitating objects, events, actions, and character in a moral category is better than humans or the world in general. In addition, in this manga story, almost all the characters (or 'actors' in Aristoteles's terminology) are aware of how to act, they really know but don't do it, eventually sinking into a puddle of suffering. According to Aristoteles, such tragic story is the worst.
\end{abstract}

Keywords : comic, manga, poetics, aristoteles, tragedy

\section{PENDAHULUAN}

Komik, atau dalam bahasa Indonesia seringkali disebut sebagai cergam (cerita bergambar), belakangan telah menemukan posisi dan urgensinya dalam keilmuan seni maupun sastra sebagai seni sekuensial, yang keberadaanya dapat diapresiasi baik dalam tinjauan seni rupa maupun sastra. Sebagaimana bentuk seni rupa yang lain, komik memiliki beberapa elemen seperti panel, gutter, balloon, caption, teks, dan tentunya gambar ilustrasi di dalam panel, yang kesemuanya itu merupakan aspek fisioplastis dari komik. Di samping itu, komik juga memiliki elemen seperti setting, gaya (bahasa), penokohan dan perwatakan, alur, titik pandang, serta tema, yang kesemuanya itu 
cenderung kepada aspek ideoplastis, dan notabene merupakan elemen prosa (sastra). Hal ini yang pada akhirnya mendudukkan komik dapat diapresiasi baik dalam perspektif kesenirupaan maupun kesusastraan (Nirwana, 2016).

Observasi yang dilakukan terhadap jurnal ilmiah dan hasil-hasil penelitian tentang komik memunculkan anggapan bahwa perhatian terhadap aspek ideoplastis (kesusastraan) dalam penciptaan komik Indonesia masih kurang. Berdasarkan pengamatan, cukup banyak dijumpai komik Indonesia yang cukup baik dari segi teknis capaian visual, namun dengan setting yang tidak original, ketidak-konsistenan dalam perwatakan, dan alur yang sulit dipahami atau terlalu sederhana. Proses pengerjaan komik yang mencakup dua hal, cerita dan gambar, dikerjakan sendiri oleh komikus nampaknya juga menjadi salah satu faktor keterabaian aspek kesusastraan ini. Komik yang bagus bukan semata-mata karena gambar yang bagus atau hubungan antar-panel yang terdefinisi dengan jelas, namun juga karakter dan perwatakan yang konsisten, alur yang kompleks, sudut pandang yang tidak biasa, atau diksi (terwujud pada teks dalam balloon atau caption) yang metaforik atau ornamental, pendeknya aspek kesusastraan yang juga dipertimbangkan dengan matang. Semisal Lord (The Legend of Three Kingdoms) (2004-2011), sebuah manga yang merupakan apropriasi dari Romance of The Three Kingdoms, dengan naskah yang dikerjakan oleh Bu Ron Son, dan gambar dikerjakan oleh Ryoichi Ikegami, mampu menunjukkan capaian teknis pengerjaan gambar dan kesusastraan yang optimal. Dalam komik ini, Bu Ron Son dan Ryoichi Ikegami telah yang keempat kalinya bekerja sama dalam produksi manga, setelah sebelumnya berkolaborasi di Strain, Sanctuary, dan Heat, lalu memenangkan Shogakukan Manga Award tahun 2002.

Dari penjabaran di atas, dapat dikatakan bahwa perhatian terhadap aspek kesusastraan menemukan urgensinya dalam pembuatan komik. Komik manga 5 Centimeters per Second (Byōsoku 5 Centimeter), yang dikerjakan oleh Makoto Shinkai (Cerita/naskah), dan Yukiko Seike (Gambar), nampaknya dapat menjadi benchmark bagaimana aspek kesenirupaan dan juga kesusastraan berkolaborasi untuk menghasilkan komik Manga yang memiliki nilai penting bagi pembaca. Komik ini mengisahkan kehidupan dua orang sahabat dekat, Tono Takaki dan Shinohara Akari. Hubungan diantara keduanya berangsur-angsur tumbuh lebih jauh, namun juga "semakin jauh" seiring berjalannya waktu. Mereka harus berpisah karena keluarga yang harus berpindah kota, namun mereka berdua terus berkomunikasi dalam bentuk surat. Seiring berjalannya waktu, kontak mereka satu sama lain mulai berhenti. Tahun berlalu, dan keretakan di antara mereka tumbuh semakin besar. Takaki mencoba mengingat-ingat saat-saat mereka bersama, lalu bertanya-tanya apakah dia akan diberi kesempatan untuk bertemu dengan Akari lagi.

Komik 5 Centimeters per Second selesai dikerjakan pada tahun 2010, dan merupakan adaptasi dari Anime dengan judul yang sama yang dibuat pada tahun 2007. Di tahun yang sama dengan selesainya Anime 5 Centimeters per Second, dibuat juga versi novelnya. Hingga saat ini, 5 Centimeters per Second terdistribusi di berbagai belahan dunia dalam 3 medium yang berbeda, anime, manga, dan juga novel, termasuk di Indonesia. Survey yang dilakukan pada situs goodreads.com menempatkan komik 5 Centimeters per Second pada posisi ke-tiga setelah We Were There (2008) karya Yuuki Obata pada urutan ke-dua, dan Nana (2005) karya Ai Yazawa pada urutan pertama, sebagai "Most depressing manga". Pada situs yang sama pula, komik 5 Centimeters per Second memperoleh rating 4.07/5.0 oleh 1.848 orang, dan telah di-review oleh 265 orang. Komik ini pertama kali diterbitkan di Jepang pada tahun 2010 oleh Kodansha Ltd. Tokyo dengan judul Byosoku 5 Centimeter dalam 2 jilid. Adapun di Indonesia diterbitkan pertama kali oleh M\&C Comics (PT 
Gramedia) dalam bahasa Indonesia dengan judul 5 Centimeters per Second pada tahun 2013.

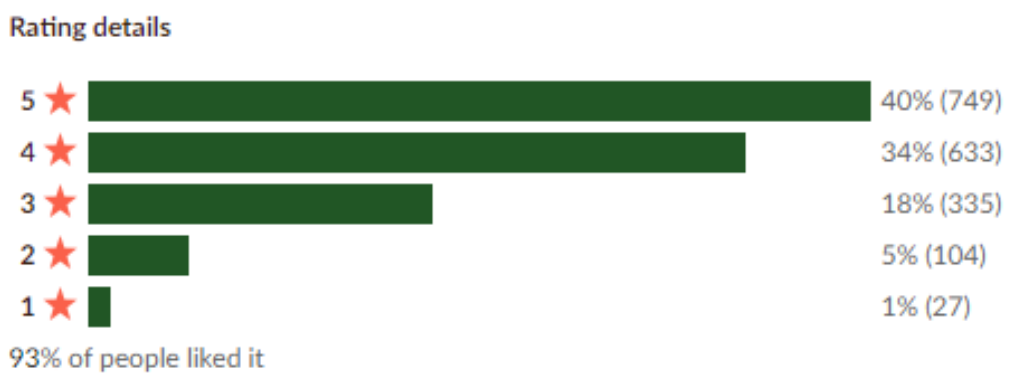

All editions: 4.07 average rating, 1848 ratings, 265 reviews, added by 3865 people, 148 to-reads

This edition: 4.07 average rating, 1793 ratings, 258 reviews, added by 3776 people

Gambar 1. Detail rating 5 Centimeters per Second di goodreads.com (sumber: www. goodreads.com, diakses pada tanggal 2 Februari 2018 )

5 Centimeters per Second mendapatkan apresiasi yang cukup tinggi dari pembaca manga dunia sebagai tragic manga atau depressing manga. Dalam genre komik, 5 Centimeters per Second dapat dikategorikan sebagai romance, namun dari sudut pandang sastra, ia dapat dimasukkan dalam kategori tragedy. Kajian ini akan menyoroti aspek kesusastraan atau aspek ideoplastis dari komik 5 Centimeters Per Second, terutama dari segi alur, karakter dan perwatakan. Dengan penjelasan mengenai alur dan perwatakan dari komik yang memiliki keunggulan dalam dua hal ini (capaian teknis visual dan kesusastraan), hasil dari kajian ini diharapkan dapat menjadi pertimbangan dalam membuat komik, terutama dalam genre romance atau tragedy.

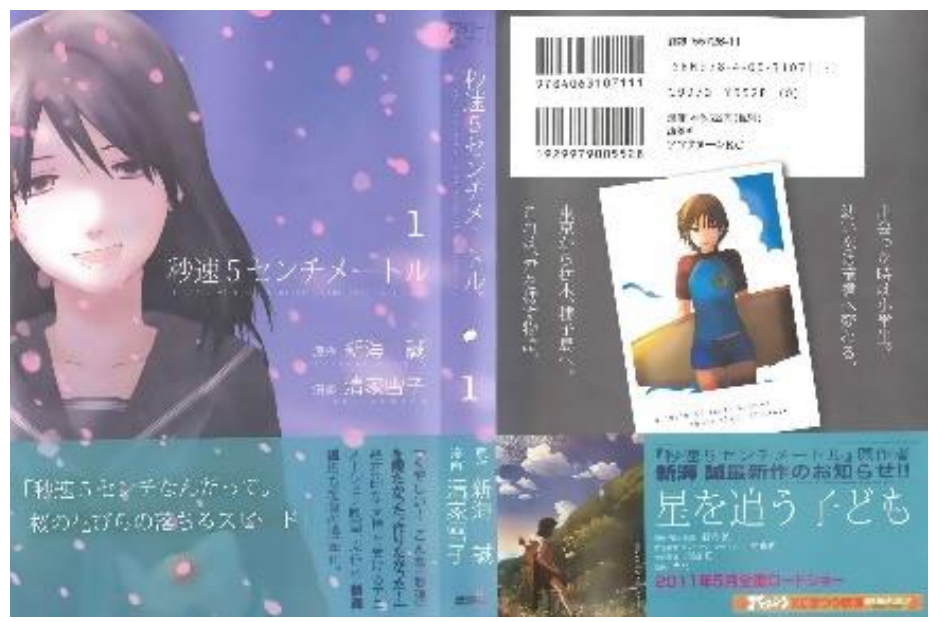

Gambar 2. Komik 5 Centimeters per Second jilid 1 (Chapter 1-5), terbitan Jepang pada tahun 2010 oleh Kodansha Ltd. Tokyo dengan judul Byosoku 5 Centimeter

Tujuan dari kajian ini adalah mengungkapkan atau menjelaskan bagaimana tragedi diungkapkan dalam komik 5 Centimeters per Second. Dalam mencapai tujuan tersebut, teorisasi dalam kajian ini dilakukan secara deduktif untuk menjawab pertanyaan penelitian. Teori yang dipergunakan untuk menjelaskan permasalahan adalah konsep Tragedy Aristoteles, yang berinduk pada karyanya Poetics sebagai karya filsafat klasik Yunani. Dalam Poetics, Aristoteles mengungkapkan bahwa Tragedi Aristoteles mendefinisikan tragedi, yakni merupakan imitasi dari tindakan (action) yang serius, menyeluruh, dan 
memiliki ruang lingkup tertentu, yang diwujudkan dengan cara bicara atau ujaran yang diperindah, dengan unsur-unsur yang terpisah, dalam lakon yang beragam, dalam tiruan yang berbentuk tindakan, bukan narasi, melalui rasa iba dan kengerian yang berimplikasi kepada penyucian jiwa melalui emosi-emosi yang muncul tersebut. Aristoteles juga mengungkapkan enam bagian (elemen atau unsur), yakni (1) Alur (mythos); (2) watak (ethos); (3) Diksi (lexis); (4) Pemikiran (dianoia); (5) Spectacle (Opsis); dan (6) Nyanyian (melos) (Butcher \& Fergusson, 1961).

Judul dari kajian ini adalah Narasi Tragis dalam Manga: Sebuah Kajian Estetika Aristotelian Terhadap Komik 5 Centimeters per Second, maka tema dari judul tersebut adalah menjelaskan bagaimana tragedi diungkapkan dalam komik 5 Centimeters per Second. Topik dari kajian ini adalah estetika komik, adapun masalah dalam kajian ini adalah aspek kesusastraan dalam komik. Secara umum, metode yang digunakan adalah metode kualitatif, atau lebih tepatnya deskriptif-kualitatif. Pemilihan desain penelitian deskriptif-kualitatif ini didasarkan kepada format desain penelitian yang lebih tepat apabila digunakan untuk meneliti masalah-masalah yang membutuhkan studi mendalam (Bungin, 2010: 69). Di samping itu, teorisasi yang dipergunakan adalah model deduksi, yakni menjadikan teori sebagai perangkat analisis (Bungin, 2010:24). Kajian ini memiliki wilayah yang sempit (fokus), yakni pengungkapan tragedi dalam narasi komik, serta variabel yang sederhana (Karakteristik peniruan (mimesis); karakteristik alur, perwatakan, kategori moral para tokoh, perumitan masalah, penyingkapan, pembalikan nasib, pemikiran (thought), spectacle; dan peristiwa/adegan tragis) namun membutuhkan kedalaman dalam pemaknaannya, karena memang terkait dengan persoalan makna, serta mempertanyakan fenomena (cara pengungkapan tragedi). Metode analisis data yang digunakan adalah analisis isi. Maka dalam pengumpulan data dipergunakan coding sheet sesuai dengan kategorisasi yang telah dibuat. Mengacu kepada objek penelitian, data yang didapat merupakan data visual maupun verbal berupa elemen-elemen komik sebagai unit analisis yang dikumpulkan dari melihat dan membaca komik, sehingga pada dasarnya, teknik pengumpulan data yang dipergunakan adalah observasi.

Secara umum metode analisis data yang dipergunakan adalah metode analisis data kualitatif. Secara spesifik dipergunakan metode analisis isi (content analysis) dengan unit analisis berupa teks dan gambar. Secara teknik, analisis isi mencakup upaya-upaya klasifikasi lambang-lambang yang dipakai dalam komunikasi, menggunakan kriteria dalam klasifikasi, dan menggunakan teknik analisis tertentu dalam membuat prediksi. Dari metodologi peneltian yang telah diuraikan maka dapat digenerasi bagan alir penelitian sebagaimana pada bagan 1 di bawah ini.

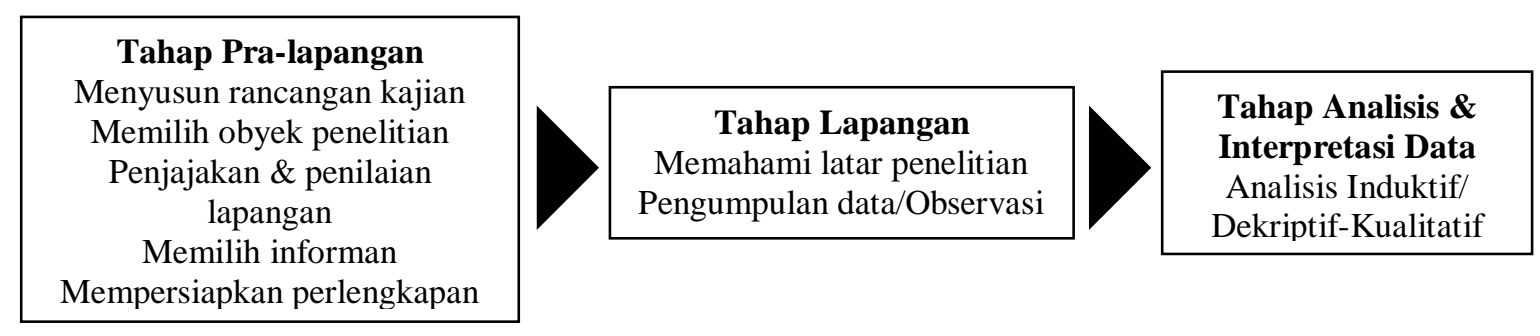

Bagan 1. Bagan Alir Penelitian

(Sumber : Diolah dari Moleong (2014:125-148)) 


\section{PEMBAHASAN}

\section{a) Pengumpulan Data}

\section{a.1) Sinopsis}

Kisah ini dimulai dari bertemunya Takaki Toono (Takaki) dan Akari Shinohara (Akari) di Tokyo ketika masih Sekolah Dasar. Takaki berasal dari Nagano dan Akari berasal dari Shizuoka. Keduanya kemudian berteman baik, hingga pada akhirnya mereka berdua harus berpisah karena ayah Akari dimutasi ke Iwafune, Tochigi. Peristiwa ini sungguh melukai keduanya, karena Akari dan Takaki telah terikat janji untuk bersekolah di SMP yang sama, SMP Nishi. Acara perpisahan SD menjadi pertemuan mereka yang terakhir waktu itu. Meskipun telah berpisah, keduanya masih saling berkirim surat. Surat Akari kembali berlabuh di loker Takaki. Mereka berdua berjanji untuk bertemu pada tanggal 4 Maret. Usai sekolah, Takaki langsung berangkat. Perjalanan yang ditempuh oleh Takaki begitu panjang ke Iwafune. Meskipun Takaki datang terlambat, Akari masih mengunggu, mereka akhirnya bertemu dan melepas kerinduan. Sebelum berpisah, keduanya saling mengungkapkan perasaan masing-masing, dan ini menjadi pertemuan terakhir sampai keduanya beranjak dewasa dan bekerja.

Semasa SMP, Takaki mengenal Kanae, hubungan keduanya menjadi semakin dekat hingga SMA. Kanae menyukai Takaki, namun ia tak juga berani mengungkapkannya kepada Takaki. Pun hati Takaki telah membeku, cintanya tetap tertambat pada Akari. Di setiap hari-harinya, Kanae terus memikirkan Takaki, namun ia tak kunjung mengungkapkan isi hatinya, Kanae merasa dirinya begitu bodoh. Takaki teringat bagaimana ia menulis dan membaca surat-surat dari Akari, lalu membalasnya. Ia juga sadar tentang bagaimana hubungannya dengan Kanae. Ia tak ingat siapa yang lebih dahulu berhenti mengirim surat, sibuk dengan dunia masing-masing, hingga kemudian mereka berdua begitu berjarak.

\section{a.2) Karakter dan Perwatakan}

Setelah dilakukan pengamatan terhadap manga 5 Centimeters per Second, berhasil didapatkan 6 karakter yang tergolong signifikan dalam cerita. Tokoh/karakter tersebut diantaranya adalah Takaki Toono, Akari Shonohara, Kanae Sumida, Mizuno Risa, Sumida, dan Ryou. Tentunya ada banyak sekali karakter dalam manga 5 Centimeters per Second, namun di luar keenam karakter ini, tidak dapat dikenali nama dan hubungannya dengan karakter utama, sehingga di luar keenam karakter tersebut dianggap kurang atau tidak signifikan dalam cerita (Simple character). Terdapat ragam karakter yang membagi pelaku menjadi dua, yakni : 1) Simple character; dan 2) Complex character. Disebut sebagai simple character ketika karakter itu tidak menunjukkan adanya kompleksitas masalah, atau tidak menunjukan adanya obsesi-obsesi batin yang kompleks. Adapun complex character adalah karakter yang pemunculannya banyak dibebani permasalahan, atau memiliki obsesi batin yang kompleks, sehingga kehadirannya banyak memberikan gambaran perwatakan yang kompleks pula (Aminuddin, 2014: 80).

Para tokoh yang terdapat dalam suatu cerita memiliki peran yang berbeda-beda. Seorang tokoh yang memiliki peranan penting dalam suatu cerita disebut dengan tokoh inti atau tokoh utama. Sedangkan tokoh yang memiliki peranan tidak penting karena pemunculannya hanya melengkapi, melayani, mendukung pelaku utama disebut tokoh tambahan atau tokoh pembantu (Aminuddin, 2014: 80). Tokoh utama dalam 5 Centimeter per Second tentunya adalah Takaki Toono, Akari Shinohara, sisanya adalah tokoh 
pembantu. Namun meskipun Kanae Sumida, Mizuno Risa, Sumida, dan Ryou merupakan tokoh pembantu, keempatnya masih tergolong complex character.

\section{a.3) Kodifikasi dan Klasifikasi Data}

Metode analisis data yang dipergunakan adalah analisis isi, maka dalam pengumpulan data dipergunakan coding sheet sesuai dengan kategorisasi yang telah dibuat. Mengacu kepada objek penelitian, data yang didapat merupakan data visual maupun verbal berupa elemen-elemen komik sebagai unit analisis yang dikumpulkan dari melihat dan membaca komik, sehingga pada dasarnya, teknik pengumpulan data yang dipergunakan adalah observasi. Observasi dilakukan dengan berfokus pada elemen-elemen dan juga adegan dalam komik yang notabene merupakan sistem/struktur yang terdiri dari elemenelemen, yang diikuti dengan pencatatan data.

Kodifikasi data adalah memberikan kode pada tiap satuan analisis/satuan data, sebelum melakukan klasifikasi data. Satuan analisis dalam kajian ini adalah adegan. Dalam kodifikasi, adegan diidentifikasi, lalu diberi kode berdasarkan format yang sudah ditentukan. Kode memuat informasi mengenai adegan, jilid buku komik, chapter, urutan adegan, dan juga halaman letak adegan. Semisal kode dari adegan tersebut adalah A.B1.01.01/5-6, maka kode tersebut menjelaskan informasi sebagaimana yang dipaparkan pada tabel 1 di bawah.

Tabel 1. Informasi yang ada pada kode A.B1.01.01/5-6

\begin{tabular}{cl}
\hline Kode & \multicolumn{1}{c}{ Keterangan } \\
\cline { 2 - 2 } $\mathrm{A}$ & Adegan \\
\hline $\mathrm{B} 1$ & Buku satu \\
\hline 01 & Story 1/Chapter 1 \\
\hline 01 & Adegan 1 \\
\hline $5-6$ & Halaman \\
\hline
\end{tabular}

Satu adegan terdiri dari beberapa panel. Untuk mengetahui beberapa panel berurutan itu adalah satu adegan, adalah jalan mengidentifikasi setting tempat dan waktu yang sama. Artinya satu adegan itu terdiri dari setting tempat dan waktu yang sama dalam satu jalinan panel berurutan. Jika panel berikutnya sudah berganti setting tempat dan waktu, berarti adegan sudah berganti. Adapun pencatatan data dengan menggunakan coding sheet dilakukan sebagaimana pada tabel 2. Pencatatan dilakukan baik terhadap buku 1 maupun buku 2.

Tabel 2. Coding Sheet pengumpulan data dari buku 1

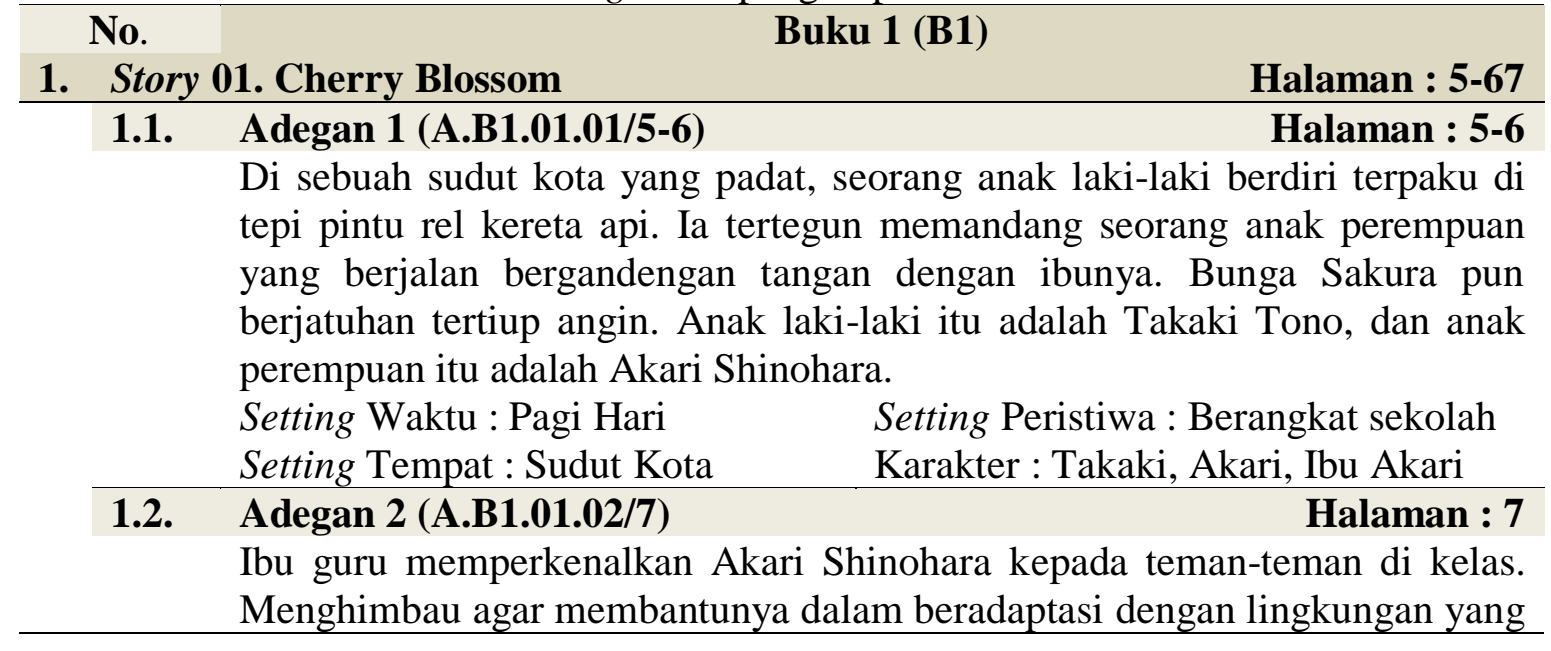


baru. Di kelas itu ada Takaki, namun mereka belum saling mengenal. Di akhir kelas, teman-teman baru Akari mengerumuninya.

Setting Waktu : Siang Hari Setting Peristiwa : Akhir kelas

Setting Tempat : Kelas, sekolah Karakter : Takaki, Akari, Ibu guru, teman-teman Akari.

1.3. Adegan dst...

Halaman : 8- dst.

\subsection{Analisis Data}

\subsubsection{Mimesis Praxeos}

Secara garis besar alur yang dikisahkan dalam manga 5 Centimeters per Second merupakan mimesis atau tiruan dari obyek, peristiwa, tindakan, manusia dan juga watakwatak. Sebagaimana yang telah diungkapkan Aristoteles mengenai letak perbedaan antara seorang penyair (seniman, sastrawan, dan juga komikus) dan seorang sejarawan, bahwa seorang penyair tidak bertugas menguraikan apa yang sesugguhnya (telah) terjadi, namun ia menguraikan apa-apa yang mungkin terjadi sesuai dengan hukum probabilitas (Aristoteles; dalam Butcher \& Fergusson, 1961: Chapter XIV). Sebuah peristiwa sungguh benar terjadi setelah diketahui, artinya, peristiwa tersebut, berikut aktor-aktor telah menjadi sejarah karena telah terjadi. Namun tidak begitu dengan kisah dalam manga 5 Centimeters per Second, dan segala hal tentang obyek, peristiwa, tindakan manusia dan juga watakwatak di dalamnya belum pernah terjadi, tetapi mungkin saja bisa terjadi pada manusia, sesuai dengan hukum probabilitas dan keniscayaan. Mimesis dalam manga ini dilakukan dengan jalan mengimitasi obyek-obyek, peristiwa, tindakan, dan watak dalam kategori moral yang lebih baik daripada manusia atau dunia pada umumnya. Mengenai itu, Aristoteles mengatakan:

"Since the objects of imitation are men in action, and these men must be either of a higher or lower type (for moral character mainly answer to these divisions, goodness and badness being the distinguishing marks of moral differences), it follows that we must represent men either as better than in real life, or as worse, or as they are. It is the same in painting. Polygnotus depicted men as nobler than they are, Pauson as less noble, Dionysius drew them true to life."

(Aristoteles; dalam Butcher \& Fergusson, 1961: Chapter II)

Dalam Poetics, Aristoteles memang tidak menjelaskan lebih jauh mengenai "kategori moral" yang lebih baik ini, berikut dengan ukuran-ukuran tentang kebaikan moral tersebut, namun istilah "moral" di sini tentunya juga harus dipahami dalam corpus Aristoteles. Untuk itu perlu ditilik Nicomachean Ethics, karya Aristoteles yang lain, yang membahas mengenai Ethics. Dalam buku tersebut, Aristoteles menguraikan secara panjang lebar ajarannya mengenai keutamaan (aretê). Aristoteles mengungkapkan bahwa seseorang dapat memperoleh keutamaan dengan berlaku baik, ia juga membagi keutamaan menjadi dua, yakni : 1) Keutamaan Moral; dan 2) Keutamaan Intelektual. Aristoteles melukiskan keutamaan moral sebagai satu sikap watak yang memungkinkan manusia untuk memilih jalan tengah antara dua ekstrem yang berlawanan, sebagaimana gagasan bangsa Yunani tentang keselarasan dan keseimbangan (Bartens, 1999: 195-197). Menentukan titik tengah diantara dua ekstrem yang berlawanan dilakukan oleh rasio, yang memberikan petunjuk untuk mengetahui apa yang harus diputuskan dalam keadaan tertentu. Untuk membimbing rasio dalam mengemban tugasnya, diperlukan kebijaksanaan yang terdiri dari : 1) Kebijaksanaan Teoretis (Sophia); dan 2) Kebijaksanaan Praktis (Phronêsis), keduanya merupakan Keutamaan Intelektual (Bartens, 1999: 198-199). 
Di samping keutamaan moral, prinsip dasar etika Aristoteles adalah bahwa manusia hendaknya hidup dan bertindak sedemikian rupa sehingga mampu mencapai hidup yang baik, yang bermutu, dan berhasil. Hidup manusia dikatakan berhasil apabila seseorang itu mencapai tujuan terakhir yang ia cari melalui segala usahanya, yaitu "kebahagiaan" (Eudaimonia). Maka etika Aristoteles disebut eudemonisme. Kebahagiaan akan semakin dapat dinikmati ketika seseorang semakin merealisasikan potensi-potensinya sebagai manusia (Suseno, 2013). Kebahagiaan dalam pengertian Aristoteles harus dapat disamakan dengan aktivitas, atau telah mencapai aktualitas, dan terdiri dari aktivitas khusus yang mengakibatkan kesempurnaan. Kesempurnaan disini adalah kesempurnaan tertinggi dari manusia yakni rasio. Oleh karena itu kebahagiaan dalam pengertian Aristoteles adalah "pemikiran", atau memandang kebenaran. Namun ada yang perlu ditambahkan lagi agar manusia dapat benar-benar bahagia, yakni menjalani aktivitasnya dengan baik. Atau sebagaimana yang dirumuskan oleh Aristoteles sendiri, agar menjadi bahagia, manusia harus menjalani aktivitasnya menurut keutamaan. Ada unsur-unsur lain yang perlu ditambahkan agar manusia menjadi bahagia, yakni kesenangan, yang merupakan usur batiniah, dan juga unsur-unsur lahiriah seperti kesehatan, kesejahteraan ekonomi, persahabatan, berkeluarga, dan juga kehormatan (Bartens, 1999: 193-195).

Meskipun tidak secara eksplisit, dalam 5 Centimeters per Second nampak bagaimana kedua karakter utama memiliki tujuan kebahagiaan hidup, terlepas dari tercapai atau tidaknya tujuan kebahagiaan itu. Takaki bericita-cita menjadi kosmonot, sedangkan Akari bercita-cita menjadi animal breeder. Kosmonot dan animal breeder tidak lain adalah potensi yang dimiliki oleh Takaki dan Akari sebagai manusia, namun keduanya belum terealisasikan. Kebahagiaan akan dinikmati oleh keduanya ketika potensi itu terealisasikan, dengan asumsi bahwa dengan tercapainya cita-cita itu diikuti dengan kesenangan, kesejahteraan, dan juga kehormatan. Cita-cita tersebut muncul pada saat keduanya sekolah dasar, dengan perkataan lain, ada tujuan kebahagiaan dari keduanya. Hal ini diekspresikan pada adegan 18, buku 1, chapter 1, halaman 29-31 (A.B1.01.18/29-31).

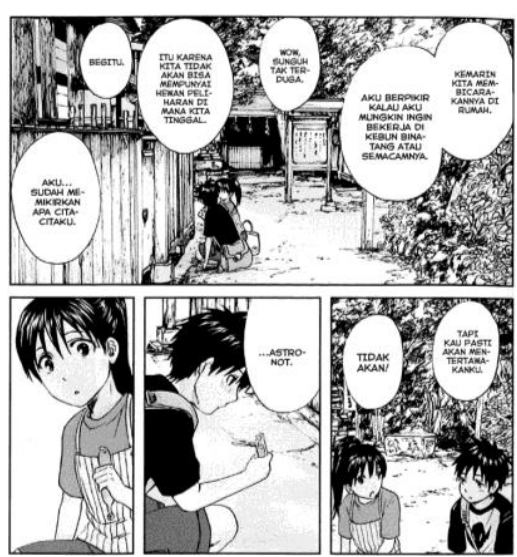

Gambar 3. adegan 18, buku 1, chapter 1, halaman 29-31 (A.B1.01.18/29-31)

(Sumber : Shinkai \& Seike, 2013)

Kehendak Takaki dan Akari untuk bersama ditampakkan dalam berbagai adegan dalam manga ini. Artinya, keduanya saling mencintai, dan memiliki harapan untuk bersatu, itulah kebahagiaan mereka. Berdasarkan pembacaan terhadap Nicomachean Ethics dan Rhetoric, Konstan (2008) menyimpulkan dua hal terkait dengan definisi cinta Aristoteles. Pertama, sangat jelas bahwa cinta yang dimaksud oleh Aristoteles ini harus bersifat altruistik. Altruisme secara umum dipahami sebagai perilaku menguntungkan orang lain dengan pengorbanan pribadi bagi individu yang berperilaku, atau dengan mudah dapat dipahami sebagai perhatian terhadap kesejahteraan orang lain tanpa memperhatikan diri 
sendiri (Kerr,dkk., 2004). Dalam realitas sehari-hari altruisme dipandang sebagai kebajikan. Kata "altruism" dicetuskan oleh filsuf Perancis Auguste Comte dalam bahasa Perancis, sebagai "altruisme", sebagai antonim dari egoisme (Teske, 2009). Dalam definisi cinta Aristoteles, sifat altruistik ini harus berlaku timbal balik (reciprocally) dalam sebuah hubungan. Namun dalam Rhetoric, Aristoteles juga menegaskan bahwa seorang filsuf harus berbagi kesenangan (pleasure), dan rasa sakit atau penderitaan (pain) kepada pihak lain (pasangan/sahabat), demi pihak lain, dan murni tanpa alasan apapun. Hal ini dimaksudkan jika pihak lain mendapatkan kebaikan, maka kita akan mendapatkan kebahagiaan yang sama, dan begitu pula sebaliknya (Konstan, 2008). Definisi cinta semacam inilah yang oleh Aristoteles disebut sebagai "philia". Pengungkapan cinta melalui hasrat altruistik, berbagi kesenangan, rasa sakit, atau penderitaan dengan tanpa alasan dalam komik ini ditunjukkan dalam banyak adegan, salah satunya pada adegan 16, buku 1, chapter 3, halaman 106-113 (A.B1.02.16/106-113).

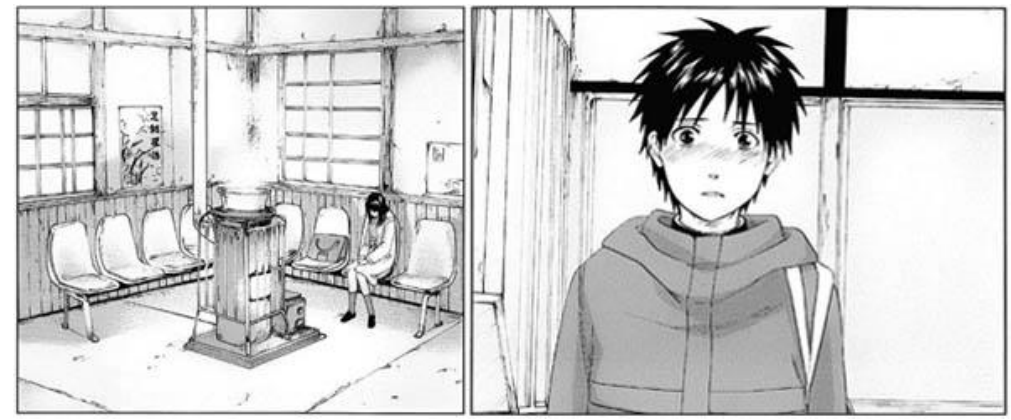

Gambar 4. Adegan 16, buku 1, chapter 3, halaman 106-113 (A.B1.02.16/106-113).

(Sumber : Shinkai \& Seike, 2013)

Kedua, Aristoteles menggambarkan cinta bukan sebagai sentimen atau perasaan, tetapi sebagai niat yang bersifat tetap (settled intention). Di sini, konsepsi Aristoteles tentang philia dan philein berbeda dari definisi "cinta" modern. Philia, masih diperdebatkan maknanya, ia dapat berarti "persahabatan" (friendship), atau "cinta" (love). Adapun philein umumnya diterjemahkan sebagai "cinta", "perhatian dengan kasih sayang", "menghargai", atau "suka", atau lebih konkretnya "memperlakukan dengan kasih sayang" (Konstan, 2008). Edisi kedua Webster's New International Dictionary (1959), misalnya, mendefinisikan "cinta" sebagai "perasaan keterikatan pribadi yang kuat" dan "kasih sayang yang kuat". Hatfield dan Rapson (2002) mengungkapkan bahwa "Cinta kasih, menggabungkan perasaan keterikatan yang mendalam, komitmen, dan keintiman". Penekanannya adalah pada perasaan, bersama dengan pengertian keterikatan dan kedekatan. Aristoteles, bagaimanapun, tidak mengatakan apa-apa tentang perasaan. Singkatnya, cinta dan persahabatan dalam Aristoteles paling baik dipahami bukan sebagai kewajiban yang berkaitan atau berdasarkan kekerabatan, tetapi sebagai hasrat altruisme yang ketika terbalas, akan menghasilkan keadaan yang oleh Aristoteles atau orang Yunani pada umumnya menyebutnya sebagai philia (Konstan, 2004).

Hasrat altruistik dalam manga 5 Centimeters per Second, pertama-tama ditampakkan oleh Takaki ketika pergi ke Iwafune, Tochigi, untuk menemui Akari (A.B1.02.03/71 A.B1.02.16/106-113). Pertemuan Takaki dan Akari ini merupakan kali pertama semenjak mereka berdua berpisah semasa sekolah dasar (adegan A.B1.01.24/41-48), dan pada saat pertemuan tersebut keduanya telah menempuh sekolah menengah. Perjalanan yang dilakukan oleh Takaki menuju Iwafune - Tochigi dari Tokyo untuk menemui Akari dapat 
dikatakan cukup berat, karena di samping jarak yang cukup jauh, cuaca buruk karena hujan salju, dan kereta yang terlambat adalah semacam siksaan batin yang dialami Takaki selama perjalanan itu. Dengan transisi panel momen ke momen yang cukup banyak, rangkaian adegan perjalanan ini berjalan sangat lambat dibanding rangkaian adegan yang lain. Di samping itu, transisi panel aspek ke aspek yang seringkali muncul "memotong" narasi, mampu memberikan impresi kepada pembaca terkait suasana hati Takaki. Di samping itu, flashback yang juga seringkali hadir dalam rangkaian adegan ini dalam transisi lokasi ke lokasi, berupa adegan yang menggambarkan peristiwa saat mereka (Takaki dan Akari) mengalami hari-hari yang indah di waktu kecil. Flashback ini tentunya memberikan jukstaposisi keadaan dahulu dan sekarang, sehingga mampu menggambarkan suasana hati Takaki yang didera pahitnya keadaan terpisah dengan Akari, dan juga dirinya yang begitu rapuh tanpa Akari. Dengan rangkaian adegan yang lambat, dan juga flashback, seakan pengarang ingin pembaca dapat ikut merasakan siksaan batin dan kerinduan yang dialami Takaki, sehingga waktu berjalan begitu lambat. Transisi antar panel momen ke momen (moment to moment) merupakan aksi tunggal yang digambarkan dalam sebuah rangkaian momen, untuk menunjukkan aksi gerak lambat, meningkatkan ketegangan, menangkap perubahan kecil, dan menciptakan gerakan seperti film di halaman komik. Adapun transisi antar panel aspek ke aspek (aspect to aspect) merupakan transisisi dari satu aspek sebuah tempat, gagasan atau suasana hati ke aspek lain, fungsinya untuk menciptakan penekanan suasana hati dan tempat yang kuat. Sedangkan transisi antar panel lokasi ke lokasi (location to location) adalah transisi melintasi jarak waktu dan/atau ruang yang sangat berbeda (McCloud, 2007: 15-17).

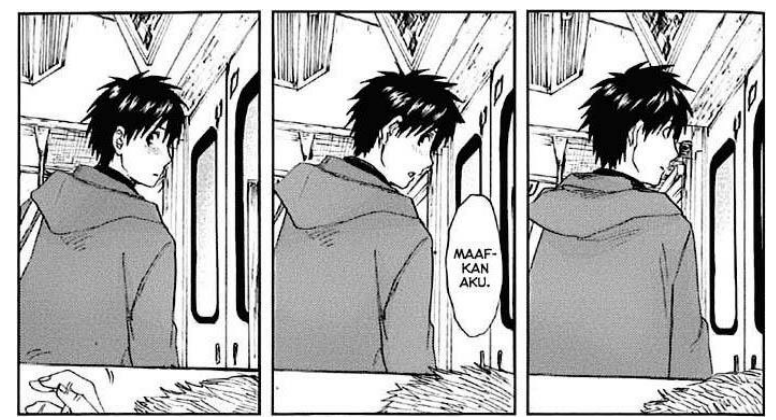

Gambar 5. Transisi antar panel momen ke momen pada adegan 12, chapter 2, buku 1

(A.B1.02.12/83-90), panel ke 6, 7, dan 8. (Sumber : Shinkai \& Seike, 2013)

Meninggalkan kegiatan sekolah untuk menempuh perjalanan jauh dalam cuaca yang buruk dan memakan waktu yang lama, berikut siksaan batin yang dialami oleh Takaki di sepanjang perjalanan menuju ke Iwafune - Tochigi tentunya merupakan suatu pengorbanan. Pengorbanan itu dilakukan oleh Takaki untuk kebahagiaan Akari, karena Takaki tahu, bahwa Akari akan bahagia jika bertemu dengannya setelah sekian lama. Takaki melakukan ini tanpa tendensi lain, kecuali demi Akari. Siksaan batin yang dialami Takaki karena terpisah dengan Akari, dan juga keadaan diri Takaki yang begitu rapuh tanpa Akari ini diperdalam oleh kekhawatiran atas Akari yang sedang menunggu dirinya di stasiun Iwafune. Kekhawatiran ini menjadi wajar karena sebagaimana janji keduanya untuk bertemu di stasiun Iwafune pukul 19.00, namun karena berbagai halangan (hujan salju yang lebat, cuaca buruk), Takaki tiba pukul 23.15, telambat 4 jam 15 menit, dan ia mendapati Akari, dalam cuaca yang sangat buruk itu, masih menunggu dirinya di stasiun. Jika mengacu pada konsep Aristoteles mengenai cinta (philia) yang menitikberatkan pada perilaku altruisme, maka kekhawatiran Takaki merupakan sebuah bentuk perhatian terhadap kesejahteraan orang lain tanpa memperhatikan diri sendiri. Sedikitpun Takaki tak 
pernah mengatakan bahwa apa yang ia lakukan selama ini merupakan sebuah bentuk pengorbanan. Perilaku yang dilakukan oleh Takaki terhadap Akari ini tentunya bersifat resiprokal (timbal-balik), karena Akari, dengan perilaku yang sama, tetap bertahan di stasiun Iwafune untuk menunggu Takaki. Bahkan, Akari telah menyiapkan makanan yang ia buat sendiri sebelumnya untuk Takaki, meskipun telah mulai dingin karena cuaca yang buruk. Perjumpaan di stasiun Iwafune ini ada pada adegan 16 (A.B1.02.16/106-113). Untuk mendramatsir adegan ini, sekaligus meningkatkan ketegangan dan suasana hati, kembali dipergunakan transisi antar panel momen ke momen. Perilaku altruistik Akari terhadap Takaki dijelaskan lebih lanjut dalam adegan A.B2.09.06/132-134. Dalam adegan tersebut, saat duduk di dalam kereta, Akari teringat kembali akan mimpinya. Dia bermimpi tentang Takaki. Akari masih percaya bahwa Takaki akan datang, walaupun sudah menunggu lama. Akari mendapat pesan masuk di ponselnya, namun tidak meresponnya. Ia teringat kembali akan Takaki, dan memikirkan apakah Takaki masih mengingatnya. Di dalam tanyanya, Akari hanya bisa mengharapkan kebahagiaan Takaki. Di hadapannya, sosok Takaki kembali muncul, yang bisa jadi sosok itu adalah bayangan, ia membayangkan Takaki kecil (semasa SMP) yang waktu itu duduk di dalam kereta menuju Iwafune untuk menemui dirinya. Dalam hal ini, keduanya memiliki perilaku altruistik terhadap satu sama lain, atau bersifat resiprokal (timbal-balik).

Di momen selanjutnya, pada adegan yang sama, masih di dalam kereta, pada panel 15, Akari mengatakan "Aku sudah benar-benar menjadikanmu kenangan kan?", selanjutnya pada panel ke-16 ia melanjutkan "Sampai pada tahap aku bisa mendoakan kebahagiaanmu”, dengan gambar ilustrasi dalam panel berupa hamparan langit cerah berawan sebagai background, dan tetumbuhan yang mengering (nampak batang, dan sedikit daun, kemungkinannya adalah semak-semak) sebagai foreground. Gambar ilustrasi tersebut dilukiskan dengan sudut pandang low angle view. Low angle adalah pengambilan gambar dalam posisi obyek berada di bawah sudut pandang mata (Maharsi, 2011:81). Secara umum penggunaan low angle shot menjadikan obyek gambar menjadi lebih kuat (strong/powerful), namun di satu sisi, "mengecilkan" pemirsa. Dari panel ke-15 menuju 16 ini, terjadi transisi antar panel aspek ke aspek, yang secara umum bertujuan untuk menciptakan penekanan suasana hati dan tempat yang kuat. Melalui sudut pandang, obyek gambar, serta tuturan Akari dalam panel ke-16 dapat dimaknai mengenai suasana hati Akari, yakni kegersangan hati karena harapan (kebahagiaan) yang tidak mampu ia raih, perasaannya terhadap Takaki telah dikalahkan oleh waktu dan jarak. Takaki telah menjadi kenangan dalam benaknya. Kegetiran ini tentunya merupakan derita batin yang harus ia tanggung dalam waktu yang cukup lama, dan ini merupakan pengorbanan besar-besaran oleh Akari. Namun, ia harus bergulat dengan kegetiran itu, mengalahkannya, hingga pada suatu tahap ia mengharapkan kebahagiaan Takaki dengan tanpa kehadirannya. Hal ini dapat dipahami sebagai pengorbanan pribadi sebagai sebuah bentuk perhatian terhadap kesejahteraan orang lain tanpa memperhatikan diri sendiri, atau perilaku yang altruistik.

Kegetiran ini, tidak hanya dialami oleh Akari, namun tentunya juga Takaki. Dalam keseluruhan plot, kehidupan Takaki memang lebih banyak terekspos ketimbang Akari. Kegetiran nyaris ia alami di sepanjang hidupnya, baik semasa SD dan SMP (Chapter/story 1-3), semasa SMA (Chapter/story 4-6), dan bahkan semasa ia dewasa (bekerja) (Chapter/story 7-10). Semasa SD, kegetiran itu a alami ketika berhadapan dengan kenyataan bahwa Akari harus pindah ke Iwafune karena mengikuti ayahnya yang bekerja. Kegetiran itu terungkap dalam ekspresi dan gestur atau tindakan, seperti pada adegan 24, chapter 1 (A.B1.01.24/41-48). Dalam adegan itu Akari menelpon Takaki, mengatakan bahwa ayahnya telah dimutasi ke Iwafune, Tochigi, dan ia akan bersekolah di SMP umum 
di sana. Takaki sungguh kecewa, padahal Akari sudah diterima di SMP Nishi. Ia telah berupaya membujuk orang tuanya agar dapat tinggal dengan bibinya di Katsushika, namun orang tuanya berkata ia masih terlalu kecil. Tidak ada pilihan lain, keduanya terpaksa berpisah dengan diiringi kesedihan yang mendalam. Akari, dengan tangisnya, tentu juga mengalami hal yang sama. Semasa SMP, kegetiran itu juga terungkap dalam adegan 14, chapter 2 (A.B1.02.14/97-104). Adegan tersebut terjadi di kereta yang mengantar Takaki ke Iwafune. Waktu menunjukkan pukul 20.58. Kembali terdengar pengumuman di dalam kereta, bahwa kereta harus berhenti untuk perbaikan kerusakan roda akibat salju. Selama itu pula Takaki merenungkan kembali, mengingat kembali kesendiriannya semenjak berpisah dengan Akari, dan ia juga yakin Akari pun demikian. Sebenarnya Takaki berniat menjalani kehidupannya dengan baik tanpa Akari, namun tidak bisa. Hujan salju semakin lebat, dan waktu telah menunjukkan pukul 22.18. Pengumuman tiba di Ashikagamebashi pun terdengar lewat pengeras suara.

Di samping terungkap dalam adegan 14, chapter 2 (A.B1.02.14/97-104), kegetiran hidup Takaki semasa SMP juga terungkap saat berpisah dengan Akari, setelah pertemuan mereka di Iwafune. Dalam adegan 10, chapter 3 (A.B1.03.10/159-160), Takaki yang berada dalam kereta, mulai merasakan keraguan, bahwa kelak mereka akan dikalahkan oleh waktu dan jarak. Ia tetap berdiri di ambang pintu kereta yang telah tertutup. Dalam panel pertama hingga yang ke-5 dalam adegan tersebut, Takaki mengatakan demikian di dalam hatinya "Aku ingin menjanjikan hal itu pada Akari (menjadi orang yang membanggakan Akari), suatu hari kelak aku akan kalah oleh waktu dan jarak yang tak terlampaui, hingga aku akan melupakan suara dan wajahmu. Bagaimana aku bisa mendapatkan kekuatan untuk melawan hal itu?". Pada masa SMA, Takaki juga masih didera oleh kegetiran itu. Plot bergerak maju ke dalam setting waktu semasa Takaki SMA, ia bersahabat dengan Kanae Sumida, yang sebenarnya menyukainya. Dalam adegan 2, chapter 5 (A.B1.05.02/203-207), mengisahkan Takaki dan Kanae pulang bersama dari sekolah seperti biasanya, hingga kemudian singgah di sebuah minimarket untuk membeli minuman. Di depan minimarket itu juga ada kotak pos, Kanae mengirim kartu ucapan musim panas di sana. Ketika Kanae menanyakan apakah Takaki juga mengirim surat ke Tokyo, Takaki hanya terdiam. Tak lama kemudian Takaki menjawab ia berkirim surat ke Tokyo, tapi saat ini sudah saling lambat membalas, dan akhirnya berhenti mengabari. Kanae berusaha menggali lebih jauh dengan mengelaborasi pertanyaan, namun Takaki mengalihkan pembicaraan. Akhirnya Takaki mengajak untuk beranjak karena ada siaran televisi yang ingin ia tonton, yakni liputan peluncuran roket H-II. Apa yang dikhawatirkan oleh Takaki semasa SMP mulai terjadi, ia akan kalah oleh waktu dan jarak yang tak terlampaui. Pun Takaki menjelaskan keadaan perasaannya kemudian, dalam adegan 12 (A.B1.05.12/227-229) dan 13 (A.B1.05.13/230-232), chapter 5. Dalam adegan 12, sepulang dari melihat roket H-II dengan Kanae, Takaki membaca buku tentang antariksa. Ia teringat cita-citanya yang pernah ia ungkapkan kepada Akari semasa SD, yakni menjadi kosmonot. Lalu Takaki mulai membayangkan Akari, sampai di mana mereka berdua akan melangkah. Ia mengetik pesan yang seolah-olah akan dikirim kepada Akari di ponselnya. Pada adegan 13, Takaki teringat bagaimana ia menulis dan membaca surat-surat dari Akari, lalu membalasnya (Flashback). Ia juga sadar tentang bagaimana hubungannya dengan Kanae. Dalam adegan tersebut Takaki menuliskan pesan di ponsel yang tak akan pernah sampai pada Akari "Aku tak ingat siapa yang berhenti mengirim surat. Tapi, bukan itu hal pentingnya, hanya saja, surat sudah kehilangan arti. Kami merangkul kekinian masing-masing hingga seolah memutus hubungan, menghindar, untuk menggapai jarak absolut di antara kami. Dan jadi hanya menyampaikan kata-kata kosong. Kukira kami akan terus bersama, kukira perasaan ini takkan berubah walau kami takkan lagi bertemu". 
Kisah saat Takaki dewasa dimulai pada chapter ke-7 (End Theme 1), di mana Takaki telah bekerja di sebuah perusahaan kontraktor, dan memiliki kekasih bernama Risa Mizuno. Dua tahun Takaki menjalin kasih dengan Risa, hingga pada suatu saat, Risa mengajak Takaki untuk bertemu orang tuanya, namun Takaki menolak. Takaki menolaknya dengan berbagai dalih, karena muncul perlawanan kuat dari dalam dirinya. Sejalan dengan hal itu, hubungan mereka berdua semakin renggang, Takaki mulai memutus komunikasi. Risa mempertanyakan apa yang sedang terjadi di antara mereka berdua, ia juga tidak ingin hubungan mereka berakhir begitu saja. Dalam adegan ke-2 dan 3, chapter 8 (A.B2.08.02/79-80, dan A.B2.08.03/81-88), Takaki meminta maaf kepada Risa karena sengaja menjadikan kesibukannya untuk tidak membalas pesan dari Risa dan tidak menyempatkan waktu untuk bertemu. Takaki merasa telah berbuat tidak adil kepada Risa. Takaki mengajak Risa pergi ke tempat yang paling tidak disukainya yaitu Iwafune. Dalam perjalanan ke sana, Risa ingin mempercepat pembicaraan Takaki dengan SMS, karena Takaki sulit untuk mengatakannya secara langsung. Lewat SMS Takaki mengungkapkan tentang pekerjaannya yang tidak membuatnya merasa bahagia, dia juga merasa takut dengan desakan-desakan Risa kepadanya sampai datang jauh-jauh ke tempat Takaki bekerja. Takaki mengaku bahwa baru kali ini dia mengungkapkan perasaannya pada orang lain, karena selama ini Takaki tidak mempercayai siapapun. Risa meminta maaf karena telah berbuat seperti itu kepada Takaki. Risa juga merasa buruk dalam mengkekspresikan dirinya. Takaki menceritakan "akulah yang salah disini", "aku tak tahu apa yang kau pikirkan", "Janganlah berbuat baik kepadaku" bahwa itulah yang orangorang katakan kepadanya, dan dia tak bisa membalas apa-apa. Takaki mengatakan semenjak dia tinggal di Tanegashima dia mulai mengikuti arus, dia bukanlah dirinya yang sebenarnya, dia menyibukkan diri dengan pekerjaan, dan merasa dirinya yang sebenarnya selalu melihat dari luar. Apabila dia melewatkan hal yang penting, dia akan meyalahkan dirinya. Risa tidak mengerti apa yang Takaki katakan. Takaki menjelaskan bahwa saat dia diberitahu untuk menemui orang tua pacarnya dan memikirkan tentang menikah, terjadi pertentangan hebat dalam dirinya. Kemudian, dalam adegan ke-5, dalam chapter yang sama (A.B2.08.05/92-103), Risa menatap Takaki, tetapi Takaki hanya diam saja dan menunduk memalingkan pandangannya dari Risa. Takaki terbayang dirinya pada masa lalu yang berdiri di depan pintu kereta. Tiba-tiba Takaki berbicara kepada Risa, dia mengakui bahwa rencananya berhenti bekerja adalah salah satu alasan agar tidak menemui orang tua Risa. Takaki merasa gagal dalam membuat kemajuan pada dirinya dan menyenangkan orang lain. Dulu dia pernah merasa tulus dan serius, tetapi setelah kehilangan perasaan itu, dia tak pernah mengampuni dirinya. Tanpa mengampuni, dia berpura-pura tidak sadar dalam menjalani hari-hari. Risa bingung dengan apa yang Takaki katakana. Takaki melanjutkan ceritanya, dia masih berharap Akari, cinta masa lalunya masih menunggunya. Dia tidak mau memberikan masa depannya pada orang lain. Tiba-tiba Takaki menyadari bahwa seharusnya dia tidak ke Iwafune bersama orang lain. Tak lama kemudian kereta berhenti dan petugas kereta mengumumkan bahwa kereta sudah sampai di Iwafune, penumpang diminta segera turun. Tetapi saat Risa telah turun dan mengajak Takaki ikut turun, ternyata Takaki yang berada didepan pintu kereta merasa bimbang dan akhirnya tidak melangkah keluar dan meninggalkan Risa dengan kata maaf. Risa menyampaikan permintaan maafnya kepada Takaki karena kegagalannya dalam memahami Takaki dari awal, dan membuat Takaki tertekan dengan sikapnya. Risa sadar bahwa perasaan Takaki kepadanya tidak cukup tulus. Risa yang sangat sedih dan terpukul, akhirnya menangis dan tersungkur di tengah jalan. Tidak mungkin bagi Risa untuk mencintai seseorang yang di dalam hatinya mencintai orang lain. Esoknya, Risa mengakhiri hubungan mereka berdua, 
meskipun di dalam hatinya masih mencintai Takaki. Dalam adegan ini, tampak bagaimana hati Takaki tak mampu beranjak dari Akari, di samping itu, kondisi ini juga diperparah dengan perasaan bersalah Takaki yang tak mampu memenuhi komitmennya dengan Akari, dan juga perasaan bersalah terhadap perempuan-perempuan yang suka padanya, dan telah ia sakiti.

Hingga pada akhir kisah hidup Takaki dalam manga ini, ia tetap merasakan kegetiran, dibarengi dengan raut wajah murung dan gestur yang lunglai. Dalam adegan 9, chapter 10, buku 2 (A.B2.10.09/168-177), Takaki pergi ke luar rumah saat bunga Sakura sedang berguguran. Di saat yang sama, di tempat yang lain, Akari juga sedang berjalan keluar. Ternyata mereka berdua berjalan menyeberangi rel kereta yang sama, tetapi mereka tidak saling melihat. Saat mereka berpapasan saling melewati, Takaki dan Akari seperti tersadar ada sesuatu yang mereka rasakan. Tetapi tiba-tiba kereta datang melewati rel itu dan menutupi pandangan Takaki yang sudah sampai diseberang rel. Takaki memandang ke arah seberang rel untuk memastikan apa yang dia rasakan adalah kehadiran Akari. Saat ketera sudah pergi jauh melewati rel disana, ternyata Akari sudah tidak ada di seberang rel. Takaki memandang dengan tatapan kecewa, tetapi setelah itu dia tersenyum dan melanjutkan perjalanannya. Lalu tergambar kenangan sosok Akari kecil yang melambaikan tangan kepada Takaki dari seberang rel. Adegan ini, sedikit banyak menggambarkan bagaimana alam batin Takaki hingga pada akhir kisahnya dalam manga ini.

Kegetiran yang nyaris ia alami di sepanjang hidupnya ini, dapat dipahami sebagai sebuah penebusan atas rasa bersalah Takaki terhadap semua itu. Takaki telah mengorbankan nyaris seluruh kehidupannya. Namun jika pengorbanan Takaki ini dibarengi dengan harapan akan kebahagiaan Akari, tentunya hal ini merupakan sesuatu yang muskil, karena bahkan keduanya tidak saling terhubung, pun kisah ini diakhiri dengan keputusan tiap tokoh untuk menjalani kehidupan masing-masing. Dalam adegan A.B2.10.09/168-177, adegan berakhir dengan senyum simpul Takaki sebelum ia kembali melanjutkan jalan dengan kemurungannya, yang dapat ditafsirkan bahwa di samping merasakan kegetiran itu, pada saat yang bersamaan, Takaki juga merasakan kebahagiaan. Sosok Akari kecil yang melambaikan tangan kepada Takaki dari seberang rel, dapat tafsirkan sebagai simbol atas harapan Takaki atas kebahagiaan Akari, dan begitu juga sebaliknya. Mereka berdua mendoakan kebahagiaan masing-masing. Akari telah berbahagia dengan kehidupannya saat ini, ia juga menikah, dan entah sampai kapan Takaki berbahagia dalam kemurungannya, atau Kanae yang berbahagia dengan kesederhanaan dalam ketidakpastian hidupnya. Hal ini sebagaimana adegan A.B2.09.06/132-134, Akari mengatakan "Aku sudah benar-benar menjadikanmu kenangan kan?", selanjutnya pada panel ke-16 ia melanjutkan "Sampai pada tahap aku bisa mendoakan kebahagiaanmu". Sikap altruistik Takaki adalah dengan mengorbankan kehidupannya, dengan harapan kebahagiaan Akari, meskipun pengorbanannya itu tidak berdampak pada kebahagiaan Akari, namun dapat dianggap sebagai perhatian terhadap kesejahteraan orang lain tanpa memperhatikan diri sendiri. Sikap altruistik ini berlangsung secara resiprokal, terjadi pula dalam kehidupan Akari.

Terlepas dari tercapai atau tidaknya tujuan kebahagian dari kedua tokoh utama, Takaki dan Akari memiliki tujuan (cita-cita) kebahagiaan hidup (eudomonia). Takaki, Akari, dan juga Kanae menggapai suatu bentuk kebahagiaan yang tidak pernah mereka cita-citakan. Takari dan Akari juga mengekspresikan hasrat altruistik mereka secara resiprokal sebagaimana konsep cinta Aristoteles (philia). Maka dari itu dapat disimpulkan bahwa manga ini hadir dengan jalan mengimitasi obyek-obyek, peristiwa, tindakan, dan watak dalam kategori moral yang lebih baik daripada manusia atau dunia pada umumnya. 


\subsubsection{Unsur Tragedi}

Cerita dari komik 5 Centimeter per Second ini memiliki struktur peristiwa yang terukur. Setiap adegan diperhatikan durasinya, sebagai contoh pada chapter 2 saat Takaki berjanji ingin menemui Akari dengan menggunakan kereta api (A.B1.02.01/69) sampai (A.B1.02.16/106-113). Dalam adegan itu tergambarkan waktu yang sangat lama karena Akari menunggu jam 19.00 di stasiun tetapi ternyata Takaki terlambat karena gangguan teknis pada kereta. Penggambaran lokasi dan jam yang ditunjukkan membuat pembaca menjadi tegang akan keterlambatan Takaki. Waktu yang terasa lama itu dapat diukur dari pemisahan gambar dalam beberapa panel. Meskipun Ada banyak panel dalam satu adegan tersebut, tetapi durasinya cukup dan tidak membosankan. Pada tiap chapter, komik ini menampilkan tokoh-tokoh yang saling berhubungan, sehingga alur cerita tetap terarah dan konsisten. Tokoh terpenting yang menghubungkan semua episode adalah Takaki. Dimulai dari kisah cinta Takaki bersama Akari semasa sekolah di chapter 1-3. Kisah Kanae bersama Takaki yang bertepuk sebelah tangan di chapter 4-6. Kisah cinta Takaki dengan Mizuno yang menyedihkan di chapter 7-9. Pertemuan tak disengaja antara Takaki dengan Mizuno, juga secara kebetulan Takaki berpapasan dengan Akari di rel kereta api, walaupun mereka tidak saling melihat pada chapter sepuluh. Terakhir di chapter 11, menceritakan Kanae yang belum menyerah pada cintanya dan mencari keberadaan Takaki. Semua cerita di tiap episodenya memiliki satu benang merah yaitu Takaki. Alur cerita dari Komik 5 Centimeter Per Second sudah cukup terkonsep dan utuh. Di tiap adegannya selalu ada penjelasan singkat mengenai latar waktu, tempat, dan adegan-adegan flashback untuk membuat pembaca tetap memahami alur cerita walaupun tokoh yang ditampilkan sudah berbeda. Bahkan untuk memperjelas alur cerita dari kisah cinta Takaki dengan beberapa wanita, komik ini menjelaskan latar belakang kehidupan dari wanita-wanita tersebut. Seperti Kanae yang hobi berselancar, sampai pada chapter 11 bercerita khusus mengenai kehidupannya. Ada juga adegan-adegan tambahan seperti menceritakan kegiatan Akari diluar kisah Takaki.

Cerita cinta pada komik ini terbilang sangat tragis dan dapat memunculkan rasa iba/ kasihan, karena pada akhirnya tidak ada yang merasakan kebahagiaan. Semua tokoh merasakan penderitaan yang disebabkan satu orang yaitu Takaki. Tetapi Takaki sendiri tersiksa hati dan batinnya karena merasa bersalah kepada banyak wanita dan tak bisa melupakan Akari, cinta masa lalunya. Tidak ada kisah cinta yang terselesaikan dalam komik ini, karena Takaki selalu lari dari kenyataan dan tidak pernah memberi kepastian. Sedangkan Akari masih bisa menjalani hidup dengan baik bahkan akan segera menikah. Pembaca akan merasa kasihan/iba terhadap kehidupan para tokoh yang tidak berujung bahagia, dan akan memunculkan rasa kesal kepada Takaki yang tidak dewasa dalam bersikap. Seharusnya jika Takaki tetap ingin bersama Akari, dia akan berusaha mencari Akari dan mengungkapkan cintanya, bukan malah merenungi nasib dan mengecewakan wanita-wanita disekitarnya. Kenyataan itulah yang membuat cerita komik ini semakin menyedihkan.

Secara keseluruhan komik ini tidak menampilkan adegan yang terjadi tiba-tiba (aksidental) atau adegan yang tidak berhubungan. Semua adegan memiliki hubungan dan tidak keluar alur cerita. Salah satu adegan yang mungkin dianggap tidak perlu seperti adegan A.B2.11.02/184-185, dimana kakak ipar Kanae mengalami kecelakaan, ternyata memiliki suatu hubungan dalam kelanjutan alur cerita. Adegan itu menjelaskan bahwa Kanae telah menjadi seorang perawat dan adegan itu juga membuat Kanae harus kembali ke sekolah lamanya yang adalah tempat kakak iparnya bekerja. Disana Kanae bernostalgia tentang masa lalunya bersama Takaki. Alur dalam komik 5 Centimeter Per Second ini 
adalah Alur yang kompleks dan bukan alur tunggal. Komik ini tidak hanya menceritakan kehidupan satu tokoh dalam tiap episodenya, tetapi menceritakan beberapa tokoh yang berkaitan dengan tokoh utamanya. Alur yang kompleks ini terdiri dari cerita kehidupan beberapa tokoh menonjolnya yaitu Takaki, Akari, Kanae dan Mizuno. Semua tokoh wanita memiliki latar belakang yang berbeda dan tinggal di tempat yang berbeda-beda pula.

Di tiap episodenya komik 5 Centimeter per second menyingkapkan teka-teki yang terjadi dalam kehidupan para Tokohnya. Seperti sebab Takaki dan Akari berpisah, kemisteriusan Takaki, Kanae yang menyukai Takaki, dan hubungan Takaki dan Mizuno yang rumit. Semuanya terjawab di tiap episodenya. Hanya saja ada beberapa adegan yang tetap membuat pembaca penasaran seperti adegan berpapasan yang tidak menunjukan wajah tokohnya, dan tentang akhir dari kisah cinta para tokoh yang menggantung. Cerita dalam komik ini lebih sering menunjukan pembalikan nasib menuju nasib yang buruk, akibat dari ketidakdewasaan Takaki dalam menggambil sikap dan keputusan. Tokohtokoh wanita seperti Kanae dan Mizuno contohnya adalah korban dari watak Takaki. Takaki juga tidak mencapai cita-citanya karena kehilangan semangat akibat kegalauan yang ada dalam dirinya. Hampir tidak ada hasil yang membahagiakan dalam kisah cinta dalam komik ini, karena itu komik ini tidak memiliki pembalikan nasib yang baik.

Terjadi banyak komplikasi dalam setiap episodenya, berbagai permasalahan muncul dan membuat banyak kontroversi. Seperti pada awal pertemuan Takaki dan Kanae saat di sekolah dasar yang sangat menyenangkan (A.B1.01.03/8-11), sampai akhirnya mereka harus berpisah karena keadaan (A.B1.01.26/52-53), (A.B1.03.10/159-160). Ada juga kisah Kanae yang selalu menjadi pengagum rahasia Takaki, sampai Kanae menyadari bahwa cintanya bertepuk sebelah tangan (A.B2.06.10/23-32). Kemudian kisah Mizuno yang harus merelakan dirinya patah hati demi kebahagiaan Takaki (A.B2.09.03/118-128). Dapat dikatakan masing-masing tokoh tidak mengalami pembalikan nasib yang baik. Semua berawal ketika Takaki bertemu dengan Akari di sekolah dasar. Mereka mulai menjadi dekat karena memiliki beberapa kesamaan, sering berbincang, pulang bersama-sama, sampai akhirnya tumbuh perasaan menyukai dan jatuh cinta. Tidak lama setelah mereka menjadi dekat, ternyata hubungan mereka harus terpisahkan oleh jarak. Akari akan pindah mengikuti orangtuanya ke Iwafune dan melanjutkan pendidikannya di sana. Semenjak kepergian Akari inilah terjadi berbagai macam permasalahan dalam kisah cinta mereka yang rumit. Sampai pada akhirnya mereka beranjak dewasa dan terputus kontak, tidak pernah saling bertemu ataupun mengetahui kabar masing-masing. Kisah cinta mereka pada akhir cerita tidak pernah berujung bahagia. Takaki memiliki nasib yang buruk karena selalu terjebak dalam cinta masa kecilnya dan tidak pernah merasakan kebahagiaan, sedangkan Akari walaupun akan segera menikah, tetapi dia tetap mengenang akan Takaki dan tidak pernah tau tentang perasaan cinta Takaki yang sebenarnya terhadap Akari.

Adapun kisah Takaki dengan Kanae yang berawal dari kekaguman Kanae terhadap Takaki, yang membuat Kanae selalu mengikuti dan memperhatikan Takaki secara diamdiam. Mereka akhirnya mulai saling berkenalan, pulang bersama, membeli minuman yang sama, dan itu semua membuat Kanae semakin jatuh hati pada Takaki. Tetapi sepertinya Takaki tidak memiliki perasaan yang sama dengan Kanae. Kisah mereka juga diakhiri dengan pembalikan nasib yang menyedihkan. Kanae harus merasakan cinta bertepuk sebelah tangan saat masa SMA-nya karena mengetahui sikap baik Takaki terhadapnya bukan karena rasa suka, dan selain itu sudah ada orang lain di hati Takaki. Patah hati Kanae terulang kembali disaat sudah dewasa, dia memutuskan pergi ke Tokyo untuk mencari Takaki demi memperjuangkan cintanya, tetapi saat sampai di Tokyo dan tidak menemukan Takaki, Kanaepun tersadar bahwa hal yang dilakukannya adalah sebuah kebodohan. Kanae juga memiliki pembalikan nasib yang tragis. Selanjutnya kisah Takaki 
bersama Mizuno. Mereka diceritakan telah menjalin hubungan cukup lama. Mereka pada awalnya memang saling tertarik dan menyukai, tetapi ada hal yang membuat Mizuno tidak pernah bisa memahami Takaki. Walaupun berpacaran dengan Mizuno, ternyata selama ini Takaki tidak pernah benar-benar mencintai Mizuno. Hal tersebut membuat hati Mizuno hancur dan memutuskan untuk meninggalkan Takaki. Dalam kisah ini, Mizuno memiliki pembalikan nasib yang juga tragis, dia harus merasakan kesedihan menjalin hubungan dengan pria yang tidak mencintainya. Dalam kisah ini, nyaris semua tokoh (atau 'aktor' dalam terminology Aristoteles) sadar bagaimana harus bertindak, mereka benar-benar tahu tetapi tidak melakukannya, akhirnya tenggelam dalam kubangan penderitaan. Menurut Aristoteles, kisah tragis seperti ini adalah yang terburuk.

Dalam komik ini terdapat ketidakseimbangan antara komplikasi dan penguraian. Terdapat pada adegan dalam chapter 2 (A.B1.02.04/72) sampai dengan (A.B1.02.16/106113). Adegan tersebut menggambarkan komplikasi yang begitu lama saat perjalanan Takaki di stasiun dan menaiki kereta untuk menemui Akari. Ada ratusan panel yang digunakan untuk menggambarkan betapa lamanya perjalanan Takaki. Banyaknya adegan tersebut dibuat agar pembaca dapat memahami perasaan cemas yang dirasakan Takaki karena tidak kunjung sampai. Yang membuat tidak seimbang adalah komplikasi pada chapter 2 yang sangat panjang diakhiri dengan penguraian sebuah adegan yang sangat singkat. Takaki akhirnya sampai di stasiun dan ternyata Akari masih menunggunya (A.B1.02.16/106-113).

\section{PENUTUP}

Secara garis besar alur yang dikisahkan dalam manga 5 Centimeters per Second merupakan mimesis atau tiruan dari obyek, peristiwa, tindakan, manusia dan juga watakwatak. Sebagaimana yang telah diungkapkan Aristoteles mengenai letak perbedaan antara seorang penyair (seniman, sastrawan, dan juga komikus) dan seorang sejarawan, bahwa seorang penyair tidak bertugas menguraikan apa yang sesugguhnya (telah) terjadi, namun ia menguraikan apa-apa yang mungkin terjadi sesuai dengan hukum probabilitas. Sebuah peristiwa sungguh benar terjadi setelah diketahui, artinya, peristiwa tersebut, berikut aktoraktor telah menjadi sejarah karena telah terjadi. Namun tidak begitu dengan manga ini, kisah dalam manga 5 Centimeters per Second, dan segala hal tentang obyek, peristiwa, tindakan manusia dan juga watak-watak di sana belum pernah terjadi, tetapi mungkin saja bisa terjadi pada manusia, sesuai dengan hukum probabilitas dan keniscayaan. Terlepas dari tercapai atau tidaknya tujuan kebahagian dari kedua tokoh utama, Takaki dan Akari memiliki tujuan (cita-cita) kebahagiaan hidup (eudomonia). Takaki, Akari, dan juga Kanae menggapai suatu bentuk kebahagiaan yang tidak pernah mereka cita-citakan. Takari dan Akari juga mengekspresikan hasrat altruistik mereka secara resiprokal sebagaimana konsep cinta Aristoteles (philia). Maka dari itu dapat disimpulkan bahwa manga ini hadir dengan jalan mengimitasi obyek-obyek, peristiwa, tindakan, dan watak dalam kategori moral yang lebih baik daripada manusia atau dunia pada umumnya.

Manga 5 Centimeter per Second ini memiliki struktur peristiwa yang terukur dengan Setiap adegan yang diperhatikan durasinya. Pada tiap chapter, komik ini menampilkan tokoh-tokoh yang saling berhubungan, sehingga alur cerita tetap terarah dan konsisten. Tokoh terpenting yang menghubungkan semua episode adalah Takaki. Alur cerita dari Komik 5 Centimeter Per Second sudah cukup terkonsep dan utuh. Di tiap adegannya selalu ada penjelasan singkat mengenai latar waktu, tempat, dan adegan-adegan flashback untuk membuat pembaca tetap memahami alur cerita walaupun tokoh yang ditampilkan sudah berbeda.Cerita cinta pada komik ini terbilang sangat tragis dan dapat memunculkan rasa 
iba/kasihan, karena pada akhirnya tidak ada yang merasakan kebahagiaan. Semua tokoh merasakan penderitaan yang disebabkan oleh satu orang yaitu Takaki. Tetapi Takaki sendiri tersiksa hati dan batinnya karena merasa bersalah kepada tokoh/aktor yang lain. Cerita dalam komik ini lebih sering menunjukan pembalikan nasib menuju nasib yang buruk, akibat dari ketidakdewasaan Takaki dalam menggambil sikap dan keputusan. Dalam kisah manga ini, nyaris semua tokoh (atau 'aktor' dalam terminology Aristoteles) sadar bagaimana harus bertindak, mereka benar-benar tahu tetapi tidak melakukannya, akhirnya tenggelam dalam kubangan penderitaan. Menurut Aristoteles, kisah tragis seperti ini adalah yang terburuk.

\section{DAFTAR PUSTAKA}

Aminuddin. (2014). Pengantar Apresiasi Karya Sastra. Bandung : Sinar Baru Algesindo.

Aristoteles. (1961). Poetics. Trans. S.H. Butcher \& Francis Fergusson. New York : Hill and Wang.

Bartens, K. (1999). Sejarah Filsafat Yunani. Yogyakarta : Penerbit Kanisius

Bungin, B. (2010). Penelitian Kualitatif : Komunikasi, Ekonomi, Kebijakan Publik, dan Ilmu Sosial Lainnya. Jakarta : Penerbit Kencana.

Chanelle, M. (2016). 5 Centimeters per Second : A Close Analysis of Two Forms of Media, dalam Mānoa Horizons - University of Hawai 'i at Mānoa, Vol. 1 (Hlm. 34-38).

Hatfield, E., \& Rapson, R. L. (2002). Passionate Love and Sexual Desire: Cross-cultural and Historical Perspectives. In A. Vangelisti, H. T. Reis, \& M. A. Fitzpatrick (Eds.) Stability and Change in Relationships. Cambridge, England: Cambridge University Press, 306-324.

Kerr, B., Smith, P.G., \& Feldman, M.W. (2004). What is Altruism?. TRENDS in Ecology and Evolution, 19(3), 135-140

Konstan, D. (2008). Aristoteles on Love And Friendship. $\Sigma X O 1 H, 2(2), 207-212$.

Maharsi, I. (2010). Komik : Dunia Kreatif Tanpa Batas. Yogyakarta : Kata Buku

McCloud, S. (2007). Memahami Komik. Jakarta : Penerbit KPG

Moleong, L. J. (2014). Metodologi Penelitian Kualitatif. Bandung : Remaja Rosdakarya.

Nirwana, A. (2016). Menyoal Komik sebagai Karya Seni Rupa dan Sastra, dalam Purnomo (Ed.) An Anthology of Scientific Articles July 2016. ISBN 978-602-9155-16-7, Universitas Ma Chung Press, Malang. (Hlm. 95-116)

Saraswati, P. S. (2014). Youkai dalam Komik Inuyasha karya Takahashi Rumiko, dalam Jurnal HUMANIS, Volume XX. No. 1. Juni 2014. (Hlm. 23-32).

Sihombing, A., dkk. (2016). Penggambaran Karakter Tokoh Utama pada Komik Doraemon Karya Fujiko F. Fujio, dalam Jurnal Japanese Literature, Volume II, Nomor 2, Tahun 2016, (Hlm. 1-9)

Subiakto, H. (2001). Analisis Isi Media, Metode, dan Pemanfaatannya, dalam Burhan Bungin (Ed.), Metodologi Penelitian Kualitatif : Aktualisasi Metodologis ke Arah Ragam Varian Kontemporer. Depok : Rajawali Press. (Hlm. 185-198)

Suseno, F.M. (2013). Eudemonisme: Epikuros dan Aristoteles, Makalah Kuliah Umum. Jakarta : Komunitas Salihara.

Teske, N. (2009). Political Activists in America : The Identity Construction Model of Political Participation. University Park, Pa.: Pennsylvania State University Press.

Yudiawati, Ni Luh Putu N.A. (2013). Mitologi Jepang dalam Komik Naruto karya Masashi Kishimoto, dalam Jurnal HUMANIS, Volume XII. No. 1. Oktober 2013. (Hlm. 1-21). 